\title{
OCCURRENCE OF CAMPYLOBACTER JEJUNI IN DIARRHOEIC AND NON-DIARRHOEIC CHILDREN IN SAOO PAULO, BRAZIL
}

\author{
Heriberto FERNANDEZ (1), M. Regina F. TOLEDo (1), Ulysses FAGUNDES NETO (2)
}

and Luiz R. TRABULSI (1*)

\section{S U M M A R Y}

Campylobacter jejuni was looked for in the feaces of 262 children, beeing 189 with acute diarrhoea, 31 with chronic diarrhoea and 42 controls. The organism was isolated from $14(7.4 \%), 2(6.5 \%)$ and $6(14.3 \%)$ of the children, and each group, respectively.

\section{N T R O D U C T I O N}

During the last decade, Campylobacter jejuni (formerly known as Campylobacter fetus subsp. jejuni) has emerged as a common agent of acute gastroenteritis 4,7. Although this organisms was known for many years as an animal pathogen, it was not until 1973, in Belgium, that it was first shown to be a common cause of diarrhoea in humans ${ }^{6}$.

Since then, C. Jejuni has been isolated practically all over the world 4,7 , and the isolations by RICCIARDI et al. ${ }^{13}$ was the first reported from Latin-America.

In this note we report the occurrence of C. jejuni in feaces of 262 diarrhoeic and nondiarrhoeic children aged 1 month to 6 years in the city of São Paulo, Brazil.

The children were divided into 3 groups:

i) Control group: 42 well nourished children followed in the.

ii) Acute diarrhoea group: 189 children with watery diarrhoea, probably of infectious etiology, with a duration of less than 10 days.

iii) Chronic diarrhoea group: 31 children with diarrhoea lasting over 2 weeks, or more than 2 attacks of diarrhoea in a period less than 3 months.

Each feacal sample was seeded in in a Butzler medium plate and incubated for 48 hours at $42^{\circ} \mathrm{C}$ under microaerophilic conditions obtained by using the GasPak system (BBL) without the catalyst 7 .

Suspected colonies were examined for vibrio-like organisms by Gram-staining and confirmed by motility in phase-contrast microscopy, positive catalase and oxidase reactions, ability to grow at $42^{\circ}$ and $37^{\circ}$ but not at $25^{\circ} \mathrm{C}$, and by sensitivity to nalidixic acid and resistance to caphalothin ${ }^{11}$.

C. Jejuni was isolated from $22(8.4 \%)$ of the 262 children examined, of which $6(14.3 \%)$ were normal, $14(7.4 \%)$ had acute diarrhoea and $2(6.5 \%)$ had chronic diarrhoea (Table I).

C. Jejuni was isolated in the 3 groups of children under study and the overall isolation rate of $8.4 \%$ falls within the ranges reported in previous surveys $1,2,6,14,15$.

In children with acute diarrhoea, the microorganism was isolated in $7.4 \%$ of the cases,

(1) Present address of senior author: Institute of Clinical Microblology; Faculty of Medicine; Universidad Austral de Chile; Valdivia - Chlle

(2) Department of Microbiology, Immunology and Parasitology, Escola Paulista de Medicina, Săo Paulo (1), and Setor de Gastro-Pediatria (2), Escola Paulista de Medicina. Rua Botucatu, 862, 3.0 andar, Vila Clementino. CEP 04023, Såo
Paulo, Bravil 
FERNANDEZ, H.; TOLEDO, M. R. F.; FAGUNDES NETO, U. \& TRABULSI, L. R. - Occurrence of Campylohacter Je funi in diarrhoele and non-diarrhoeic children in Säo Paulo, Brazll. Rev. Inst. Med. trop. São Paulo 27:102-104, 1985.

rate that is similar to that obtained by SKIRROW in England 14. However it is lower than those found in developing countries 1,2,5 but higher than that reported by RICCIARDI et al. ${ }^{13}$, in Rio de Janeiro.

The incidence of Campylobacter isolations $(6.5 \%))$ in children with chronic diarrhoea was lower than that reported by these Brazilian Authors ${ }^{13}$. Considering that the review of the literature did not provide more data on the Isolation of this bacteria from stools of chronic diarrhoeic patients, it would be necessary to conduct further studies in order to establish a possible role of $\mathbf{C}$. jejuni in chronic diarrhoeic process. It could be particularly important in patients with tropical enteropathy, in which certain enterobacteria are isolated from jejunal aspirates, and which malabsorption is regularly present 9,10 . Because of its ability to multiply in bile ${ }^{3}$, $C$. jejuni could proliferate in the bilerich small intestine producing like Escherichia coli, Klebsiella pneumoniae or Enterobacter cloacae, the malabsorption process observed in tropical enteropathy. In one experiment, ma- labsorption of sugars was demonstrated in mice inoculated with C. jejuni 12. On the other hand, C. jejumi was previously isolated from jejunal aspirates of a child with chronic diarrhoea but not from acute diarrhoeic children ${ }^{8}$. In our study, the 2 children with chronic diarrhoea, in which Campylobacter was found in stools, also had tropical enteropathy, and in one of them, the organism was also isolated from jejunal aspirate.

Contrasting with European and American findings $4,6,14$, we found that the isolation rate of C. jejuni in normal children (14.3\%) is high, but is in agreement with the results obtained in tropical developing countries 1,2,5. This fact complicates the interpretation of the isolation of Campylobacter in children with diarrhoea, opening a new question related to the pathogenic mechanisms of this bacteria. On the other hand, the role of socioeconomic conditions in influencing and determining the distribution of C. jejuni, is an aspect that must be elucidated for a better understanding of the epidemiology of Campylobacter enteritis.

T A B I $\mathbf{T} I$

Isolation of Campylobacter jejunl from diarrhoelc and non-diarrhoelc children

\begin{tabular}{|c|c|c|c|c|c|}
\hline \multirow{2}{*}{ Children } & \multicolumn{3}{|c|}{ Number of faecal cultures } & \multirow{2}{*}{\multicolumn{2}{|c|}{ Positivity }} \\
\hline & Positive & Negative & Total & & \\
\hline Non-diarrhoeic & 6 & 36 & 42 & 14.3 & \\
\hline With acute diarrhoes & 14 & 175 & 189 & 7.4 & \\
\hline With chronic diarrhoes & $\mathbf{2}$ & 29 & 31 & 6.5 & \\
\hline Total & 22 & 240 & 262 & 8.4 & \\
\hline
\end{tabular}

\section{RESUMO}

\section{Ocorrência de Campylobacter jejuni em crian- ças com diarréia e normais em São Paulo, Brasil}

Campylobacter jejuni foi pesquisado nas fezes de 262 crianças, sendo 189 com diarréia aguda, 31 com diarréia crônica e 42 sem sintomatologia gastrintestinal. A bactéria foi encontrada em $14(7,4 \%), 2(6,5 \%)$ e $6(14,3 \%)$ das crianças, em cada um dos grupos, respectivamente.

\section{REFERENCES}

1. BILlinghaM, J, D. - Campylobacter enteritis in the Gambia. Trans. R. Soc. Trop. Med. Hyg. 75: 641-644, 1981
2. BLASER, M. J.; GLASS, R. I.; HUQ, M. I.; STOLL, B.; KIBRIYA, G. M. \& ALIM, A. R. M. A. - Isolation of Campylobacter fetus ssp. Jejunl from Bangladeshi children. J. Clin. Microbiol. 12: 744-747, 1980.

3. BLASER, M. J.; HARDESTY, H. L.; POWERS, B. \& WANG, W. L. L. - Survival of Campylobacter tetus subsp. Jejuni in biological milieus. J. Clin. Microblol. 11: $309 \cdot 313,1980$.

4. BLASER, M. J. \& RELLER, L. B. - Campylobacter enteritis. New Engl. J. Med. 305: 1444-1452, 1981.

5. BOKKENHEUSER, V. D. ; RICHARDSON, N. J.; BRY. NER, J. H.; ROUX, D. J.; SCHUTTE, A. B.; KOORNHOF, H. J.; FREIMAN, I. \& HARTMAN, H. - Detection of enteric campylobacteriosis in children. $J$. Clin. Microblol. 9: 227-232, 1979.

6. BUTZLER, J. P.; DEKEYSER, P.; DETRAIN, M. \& DEHAEN, F. - Related "vibrio" in stools. J. Pedlatr. 82: $493-495,1973$. 
FERNANDEZ, H.; TOLEDO, M. R. F.; FAGUNDES NETO, U. \& TRABULSI, L. R. - Occurrence of Campylobacter Je. funl in diarrhoeic and non-diarrhoeic chlldren in São Paulo, Bravil. Rev. Inst. Med. trop. São Paulo 27:102-104, 1985.

7. BUTZLER, J. P. \& SKIRROW, M. B. - Campglobacter enteritis. Clin. Gastroenterol. 8: 737-765, 1979.

8. CADRANEL, S.; RODESH, P.; BUTZLER, J. P. \& DEKEYSER, P. - Enteritis due to "related vibrios" in children. Am. J. Dis. Chlld. 126: 152-155, 1973.

9. KLIPSTEIN, F. A.; HOLDEMAN, L. V.; CORCINO, J. J. \& MOORE, W. E. C. - Enterotoxigenic Intestinal bacteria In tropical sprue. Ann. Int. Med. 79: 632. $641,1973$.

10. KLIPSTEIN, F. A.; SHORT, H. B.; ENGERT, R. F.; JEAN, L. \& WEAVER, G. A. - Contamination of the small intestine by enterotoxiginec colfform bacteria among the rural population of Haiti. Gastroenterology 70: 1035-1041, 1976.

11. LUECFTEFELD, N. W.; WANG, W. L. L; BLASER, M. J. \& RELLER, L. B. - Campylobacter fetus subsp. jejunt: background and laboratory diagnosis, Lab. Med. 12: 481.487, 1981.
12. MADGE, D. S. - Campglobacter enteritis in young mice. Digestion 20: 389.394, 1980.

13. RICCIARDI, I. D.; FERREIRA, M. C. S.; OTTO, S. S.; OLIVEIRA, N.; SABRA, A. \& FONTES, C. F. - Thermophilic Campylobacter assoclated diarrhoea in Rlo de Janeiro. Rev. Bras. Pesquilsas Méd. e Biol. 12: 189-191, 1979.

14. SKIRROW, M. B. - Campylobacter enteritis: a "new" disease. Br. Med. J. 2: 9-11, 1977.

15. SMITH, J. P.; DURFEE, K. \& MARYMONT Jr., J. H. - Incidence of Campylobacter enteritis in the Midwestern United States, Am. J. Med. Technol, 48: $81-84,1880$.

Recebido para publicaçăo em 23/6/1983. 